\title{
超音波パルスドップラ法におけるパルスの繰り返し回数と ノイズによる速度分布計測への影響*
}

\author{
村川 英樹 ${ }^{* 1}$, 大上 陽 ${ }^{* 2}$, 杉本 勝美 ${ }^{* 1}$, 竹中 信幸 ${ }^{* 3}$

\section{Effect of Number of Pulse Repetition and Noise on Velocity Profile Measurement in Ultrasonic Pulse Doppler Method}

\author{
Hideki MURAKAWA ${ }^{* 1}$, Akira OUE, \\ Katsumi SUGIMOTO and Nobuyuki TAKENAKA \\ ${ }^{*}$ Kobe Univ. Dept. of Mechanical Engineering \\ 1-1 Rokkodai, Nada, Kobe, 657-8501 Japan
}

\begin{abstract}
Ultrasonic pulse Doppler method has been widely used in many engineering field referred to as UVP (ultrasonic velocity profiler). Analysis algorithm in the UVP, number of pulse repetition $\left(N_{\text {pulse }}\right)$, noise and reflector conditions, etc. may affect on the measurement accuracy. The $N_{\text {pulse }}$ is related to the temporal resolution, and must be set as low as possible in order to improve the temporal resolution. However, it is known that accuracy of instantaneous velocity becomes worse with decreasing of the $N_{\text {pulse. }}$. In this study, effect of analysis algorithm in the UVP on velocity data was investigated with changing of the $N_{\text {pulse }}$ and SNR by simulation and experiments. As a result, it is shown that there is an appropriate $N_{\text {pulse }}$ in each algorithm depending on the SNR. An algorithm which decides the Doppler frequency from maximum value in the power spectrum, FFT-max, was relatively hard to be affected by noise. Difference of velocity standard deviation was small between lower and higher noise conditions when FFT-max with $N_{\text {pulse }}$ over the appropriate value was used for the calculation. Hence, FFT-max was the best analysis algorithm for measuring flow field compared with the autocorrelation.
\end{abstract}

Key Words : UVP, Velocity Profile, FFT, Autocorrelation, Analysis Algorithm

\section{1. 緒言}

超音波パルスドップラ法は，医療分野において血流量を計測する手法として開発されてきた ${ }^{(1)}$. 本手法は非接 触に計測できること，不透明流体や不透明配管に適用可能であること，瞬時の一次元速度分布が得られることか ら, Takeda ${ }^{(2)}$ にって工学分野への適用がなされた．工学分野では本手法をUVP（ultrasonic velocity profiler）と呼

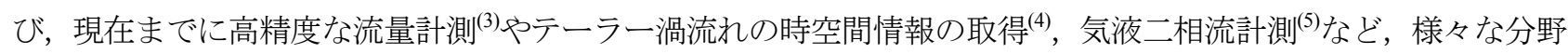
において用いられている(6).

超音波が移動体に反射すると, 移動体の速度に応じたドップラ周波数 $f_{d}$ が基本周波数 $f_{0}$ に付加され, それを解 析寸ることで速度を求めることができる. しかしながら，超音波計測では一般に $f_{0}$ に対して $f_{d}$ は小さく，さらに スペクトル幅が広いため，1 回の超音波パルスのエコー信号から $f_{d}$ を解析することは困難である，そこでパルス ドップラ法では一般的に複数回のエコー信号から $f_{d}$ を求めている. 一つの速度算出に用いる超音波パルスの繰り 返し回数は，多くするほじ瞬時の速度分布は良好に計測できるものの，計測に要する時間が長くなる．医療分野 において近年多く用いられているカラードップラ法(7)は二次元断層面の流速を計測し，リアルタイム画像を表示 する手法である．そのため，少ないパルスの繰り返し回数によって高速な速度算出が行われている．流体計測に

*原稿受付 2012 年 10 月 9 日

*1 正員, 神戸大学大学院工学研究科（率657-8501 兵庫県神戸市灘区六甲台町 1-1）

*2 学生員, 神戸大学大学院工学研究科

*3 正員, フェロー, 神戸大学大学院工学研究科

E-mail: murakawa@mech.kobe-u.ac.jp 
おける UVP 計測では，定量的な速度分布を取得するために高精度な計測が求められており，一般的に医療用よ り多い $2^{5} \sim 2^{7}$ 回程度のパルスの送受信によって瞬時速度を算出している. パルスの繰り返し回数は，多くするほ ど時間分解能が低下し，早い速度変動が計測できなくなる，そのためパルスの繰り返し回数による速度変動への 影響を評価することは, 速度場計測において重要である.

パルスドップラ法の計測精度に影響する要因として, 一つの速度を算出するのに用いる超音波パルスの繰り返 し回数, 複数のパルスから $f_{d}$ を求める周波数解析アルゴリズムに加え，ノイズ，測定体積および反射体の粒子濃 度などが挙げられる．従来，基本周波数のスペクトル成分の違いによる影響(8)，反射体による超音波散乱による 影響(9)，速度算出アルゴリズムとノイズによる速度追従性への影響(10)などについて報告がなされている．これら は主に血流測定を対象に行われてきた. UVP 計測では, 得られた速度の標準偏差を評価するうえで, 血流の脈動 より早い速度変動に対する精度を把握することが重要である.さらに血管内に比べ一般的に計測範囲が広く, SN 比（SNR）も大きく変化する. しかしながら流体計測を対象として, パルスの繰り返し回数とノイズによる速度 変動への影響を評価した例は，これまでほとんじ示されてこなかった，そのため実際のUVP 計測では，経験的 に繰り返し回数を設定してきた.

そこで本研究では, パルスドップラ法を用いた流体計測において, 最適なアルゴリズムと超音波パルスの繰り 返し回数の決定方法を示すことを目的とし，擬似ドップラ信号を用いたシミュレーションおよび実際の流れ場計 測において, 周波数算出アルゴリズム, 超音波パルスの繰り返し回数およびノイズによる速度变動への影響を評 価した.

\section{2. 周波数解析アルゴリズム}

パルスドップラ法におけるドップラ周波数算出手法の模式図を図 1 に示寸. 超音波の測定線上の各位置で生じ るエコー信号から速度分布を算出するため, 超音波パルスを連続的に送受信する. パルス $n$ 番目, 計測位置 $i$ で の反射信号を受信するまでの遅れ時間 $t_{n, i}$ は，最初のパルスを発信した時刻を基準とすると

$$
t_{n, i}=n T_{p r f}+\frac{2 l_{i}}{c}
$$

となる.ここでcは音速， $T_{p r f}$ は超音波の発信間隔であり $T_{p r f}=1 / f_{p r f}$ である. 連続的に移動する反射体によって生じる 反射信号 $s(t)$ は，Aを振幅，超音波の基本周波数を $f_{0}$ とすると

$$
\begin{aligned}
s(t) & =\sum A_{n, i} \cos 2 \pi f_{0}\left(t-t_{n, i}+\frac{2 n \Delta x}{c}\right) \\
& \approx \sum A_{n, i} \cos 2 \pi\left\{f_{0}\left(t-t_{n, i}\right)+f_{d, i} n T_{p r f}\right\}
\end{aligned}
$$

と表せる.ここで $T_{p \nmid \jmath}$ の時間間隔において, 反射体が $\Delta x$ 移動するものとした. すなわちドップラ法では, 反射体の 移動によって生じるエコー信号の位相変化を検出することで, 各計測位置における反射体の速度を計測すること ができる，位相変化を算出するためには，複数回の超音波パルス送受信が必要となる．このパルスの繰り返し回 数を $N_{\text {pulse }}$ とし, $N_{\text {pulse }}$ が多いほど一つの速度算出に要する時間が長く, 時間分解能が低下する. 


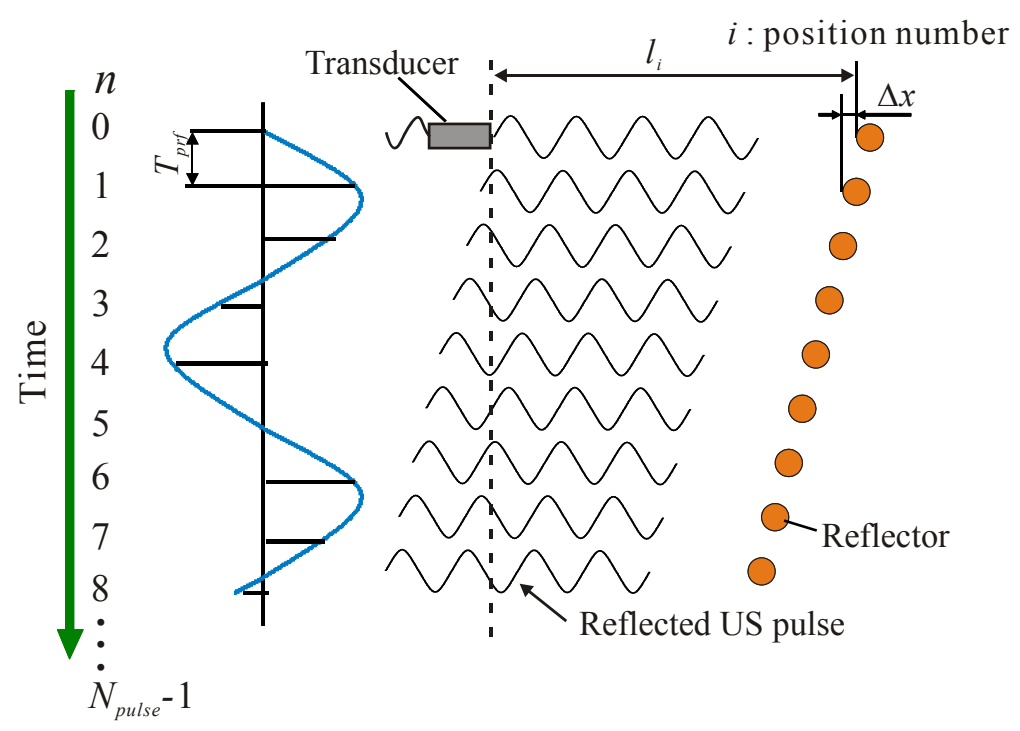

Fig.1 Detection of the Doppler frequency

図2に計測システムのブロック線図を示す. 超音波パルサ・レシーバによって送受信したエコー信号を高速デジ タイザによってサンプリングし, 基本周波数の $\cos$ 成分, sin成分の積を求め, それぞれの信号にローパスフィルタ の処理を行い，搬送波の周波数成分を除去する.

$$
\begin{aligned}
z_{i}(t) & =\left\{2 s(t) \cdot e^{j 2 \pi f_{0} t}\right\}_{\text {LowPass }}=x_{I}(t)+j x_{Q}(t) \\
& =\sum A_{n, i} \cos 2 \pi\left(f_{d, i} n T_{p r f}-f_{0} t_{n, i}\right)-j \sum A_{n, i} \sin 2 \pi\left(f_{d, i} n T_{p r f}-f_{0} t_{n, i}\right)
\end{aligned}
$$

この操作は直交検波と呼ばれ, 速度方向の判別が可能となる. 以上の過程を $t_{n, i}=n T_{p r f}+\tau_{i}$ によって標本化すると

$$
\begin{aligned}
z_{i}[n] & =x_{I}\left(t_{n, i}\right)+j x_{Q}\left(t_{n, i}\right) \\
& =x_{I, i}[n]+j x_{Q, i}[n] \\
& =A_{n, i} \cos \left(2 \pi f_{d, i} n T_{p r f}-\varphi_{i}\right)-j A_{n, i} \sin \left(2 \pi f_{d, i} n T_{p r f}-\varphi_{i}\right)
\end{aligned}
$$

となる．ここで $\varphi_{i}$ は初期位相とのずれを表す．よってこれらの信号に対して周波数解析を行うことで，各位置の ドップラ周波数 $f_{d, i}$ を算出し, 以下の式を用いて速度を算出する.

$$
v_{i}=\frac{c f_{d, i}}{2 f_{0}}
$$

式(4)からドップラ周波数を算出するための周波数解析には，一般的に短時間高速フーリエ変換（FFT）および 自己相関法 ${ }^{(11)}$ が用いられている.

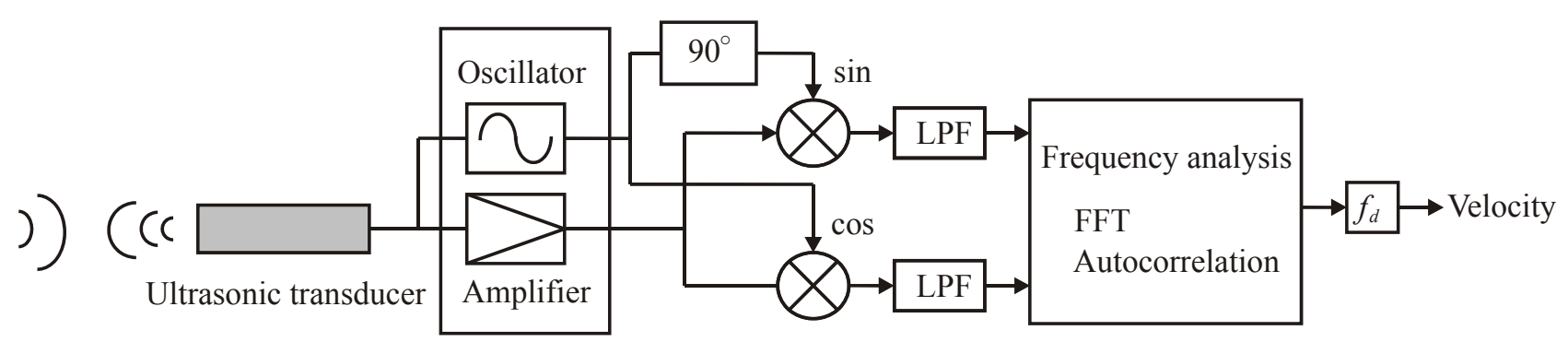

Ultrasonic pulser/receiver

Fig.2 Block diagram of the measurement system 
$x_{I, i}[n]$ と $x_{Q, i}[n]$ の離散フーリエ変換を $X_{I, i}\left(f_{k}\right)$ と $X_{Q, i}\left(f_{k}\right)$ とすると，周波数のパワースペクトル $P_{i}\left(f_{k}\right)$ は

$$
\begin{aligned}
& P_{a, i}\left(f_{k}\right)=\left\{\operatorname{Re}\left(X_{I, i}\left(f_{k}\right)\right)-\operatorname{Im}\left(X_{Q, i}\left(f_{k}\right)\right)\right\}^{2}+\left\{\operatorname{Re}\left(X_{Q, i}\left(f_{k}\right)\right)+\operatorname{Im}\left(X_{I, i}\left(f_{k}\right)\right)\right\}^{2} \\
& P_{t, i}\left(f_{k}\right)=\left\{\operatorname{Re}\left(X_{I, i}\left(f_{k}\right)\right)+\operatorname{Im}\left(X_{Q, i}\left(f_{k}\right)\right)\right\}^{2}+\left\{\operatorname{Re}\left(X_{Q, i}\left(f_{k}\right)\right)-\operatorname{Im}\left(X_{I, i}\left(f_{k}\right)\right)\right\}^{2}
\end{aligned}
$$

となる．ここで添え字 $a$ はセンサから遠ざかる成分， $t$ はセンサに近づく成分を示す．スペクトルの平均值より $f_{d, i}$ は,

$$
f_{d, i}=\frac{\sum_{k=0}^{N_{\text {pulse }} / 2} f_{k}\left(P_{a, i}\left(f_{k}\right)-P_{t, i}\left(f_{k}\right)\right)}{\sum_{k=0}^{N_{\text {pulse }} / 2}\left(P_{a, i}\left(f_{k}\right)+P_{t, i}\left(f_{k}\right)\right)}
$$

で求めることができる．以降，式(7)より $f_{d}$ を求める手法をFFT-aveと示す.

パワースペクトルから $f_{d}$ を求める手法として, FFT-aveに加えスペクトルの最大值となる周波数を $f_{d}$ とする手法 が考えられる. FFTでは有限な長さの時間周波数空（N $N_{\text {pulse }}$ に相当）を用いるため, 時間分解能と周波数分解能の 間にはトレードオフの関係が生じる，高い時間分解能を得るために時間空を短くすると，周波数空が広くなり， 周波数分解能が低下寸る. 反対に高い周波数分解能を得るために周波数空を小さくすると時間空が長くなり, 時 間分解能が低下寸るため, $N_{\text {pulse }}$ をあまり小さくできないという久点がある. そこで $P_{a}\left(f_{k}\right)$ および $P_{t}\left(f_{k}\right)$ で最大值とな る周波数を $f_{\max }$ とし, 図3に示寸ように, その前後の周波数の值からガウス補間によって $f_{d}$ を求めることで, 少ない

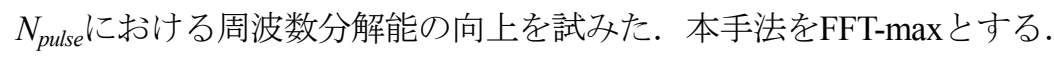

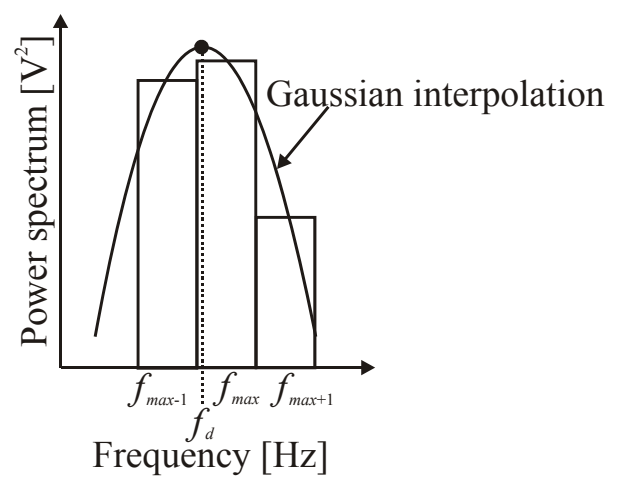

Fig.3 Detection of $f_{d}$ using Gaussian interpolation (FFT-max)

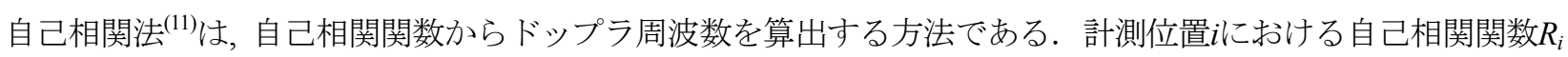
は,

$$
\begin{aligned}
R_{i} & =\sum_{n=0}^{N_{\text {puls }}-2} z_{i}[n] \times \overline{z_{i}[n+1]} \\
& =\sum_{n=0}^{N_{\text {pulse }}-2}\left(x_{I, i}[n] x_{I, i}[n+1]+x_{Q, i}[n] x_{Q, i}[n+1]\right)+j \sum_{n=0}^{N_{\text {pulse }}-2}\left(x_{I, i}[n+1] x_{Q, i}[n]-x_{I, i}[n] x_{Q, i}[n+1]\right) \\
& =R_{x, i}+j R_{y, i}
\end{aligned}
$$

となり, ドップラ周波数 $f_{d, i}$ を

$$
f_{d, i}=\frac{1}{2 \pi T_{p r f}} \tan ^{-1} \frac{R_{y, i}\left(T_{p r f}\right)}{R_{x, i}\left(T_{p r f}\right)}
$$


で求めることができる. 自己相関法は, 少ない $N_{\text {pulse }}$ で高速に速度推定が可能であることから, 市販のUVP装置

(UVP-Duo, Met-Flow S.A.) や医療分野で多く用いられている手法である. 原理上 $N_{\text {pulse }}=2$ で瞬時の位相変位を算 出できるが, 実際の計測ではノイズによる影響が大きく, SNRを向上させるために複数回の超音波送受信が必要 である.

\section{3. 擬似ドップラ信号によるシミュレーション}

\section{$3 \cdot 1$ 解析方法}

疑似ドップラ信号を算出するため，レーザドップラ流速計（LDV，Smart LDV II，日本カノマックス）を用い て時系列速度データを取得した，計測は幅 $50 \mathrm{~mm}$ ，高さ $25 \mathrm{~mm}$ の水平矩形流路における中心で，主流の速度成分 をサンプリング周期 $2 \mathrm{kHz} （ f_{p r f}$ に相当）で取得した. 同じ速度值が連続的に取得された場合は，その間にデータ が計測されなかったものとみなし，それらを取り除くことで時系列速度データ $v(\tau)$ と，これを真值として取り 扱った. 作動流体は $20 \sim 25^{\circ} \mathrm{C}$ 水で, レイノルズ数 $R e=5000$ とした.

得られた $v(\tau)$ に, 以下の周波数変調を行うことで疑似ドップラ信号とした ${ }^{(12)}$.

$$
f m_{c}(t)=\cos \left(\frac{4 \pi f_{0}}{c} \sum_{\tau=0}^{t} \frac{v(\tau)}{f_{p r f}}\right), \quad f m_{s}(t)=\sin \left(\frac{4 \pi f_{0}}{c} \sum_{\tau=0}^{t} \frac{v(\tau)}{f_{p r f}}\right)
$$

超音波計測では, その広い周波数帯域に加え, 減衰などにより SNR の低下が計測結果に影響を及ぼす. そこで 本研究では, 擬似ドップラ信号に SNR $=20 \mathrm{~dB}, 5 \mathrm{~dB}$ のホワイトノイズを付加して, FFT-ave, FFT-max および自 己相関法によるドップラ周波数解析を実施した. 真の速度である $v(\tau)$ と比較するため, 瞬時速度の誤差の二乗平 均 $\sigma$ を以下の通り定義した. $v_{D}(\tau)$ は疑似ドップラ信号から求めた瞬時速度, $N$ はデータ数である.

$$
\sigma=\sqrt{\frac{\sum\left(v(\tau)-v_{D}(\tau)\right)^{2}}{N}}
$$

超音波はトランスデューサから距離が離れるにつれて音圧強度が低下し，反射体によって生じる反射波強度も 低下寸る．そのため実際のUVP 計測では，計測位置がトランスデューサから離れるにつれて SNR が低下寸る. UVP による速度分布計測が適切に行える超音波送信電圧および受信ゲインの設定において, 流路内における SNR は 20 0 dB 程度であることを確認している.

\section{$3 \cdot 2$ 解析結果}

図 4 に LDV および自己相関法を用いて解析した時系列速度データを示寸．それぞれ $N_{p u l s e}=4, \quad N_{p u l s e}=16$ で， イズが無い条件，および $\mathrm{SNR}=20 \mathrm{~dB}$ のホワイトノイズを付加した条件である．ノイズが無い条件では $N_{p u l s e}=4$, すなわち時間分解能が高くなるにつれ，LDVによって計測された短時間の速度変動が再現でき, $N_{p u l s e}$ が大きくな るにつれて時間平均された速度が算出されることがわかる. $\mathrm{SNR}=20 \mathrm{~dB}$ の $N_{\text {pulse }}=4$ では, ノイズの影響により LDV に比べて瞬時速度が大きくずれている．時間分解能が低下寸るにつれて瞬時速度が時間平均されるため，， イズによる計測誤差に起因した速度変動が少なくなっていることが確認できる. 


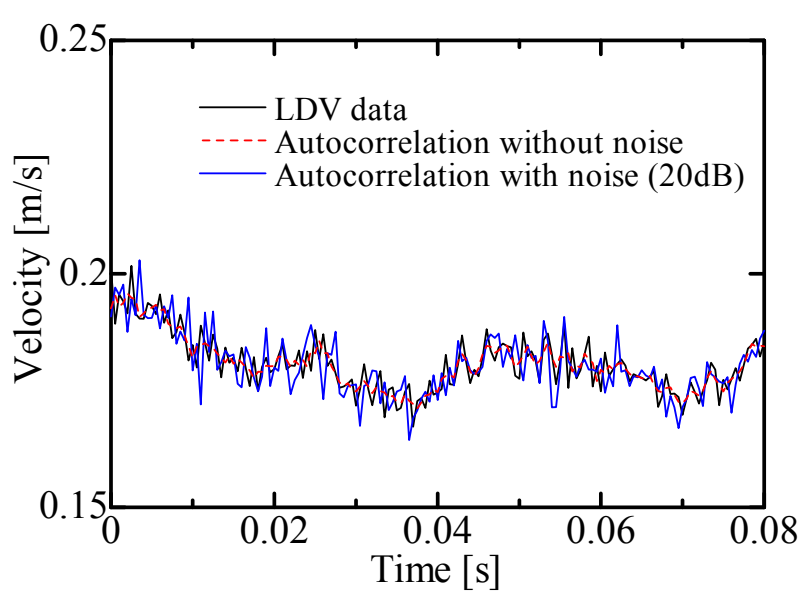

(a) $N_{\text {pulse }}=4$

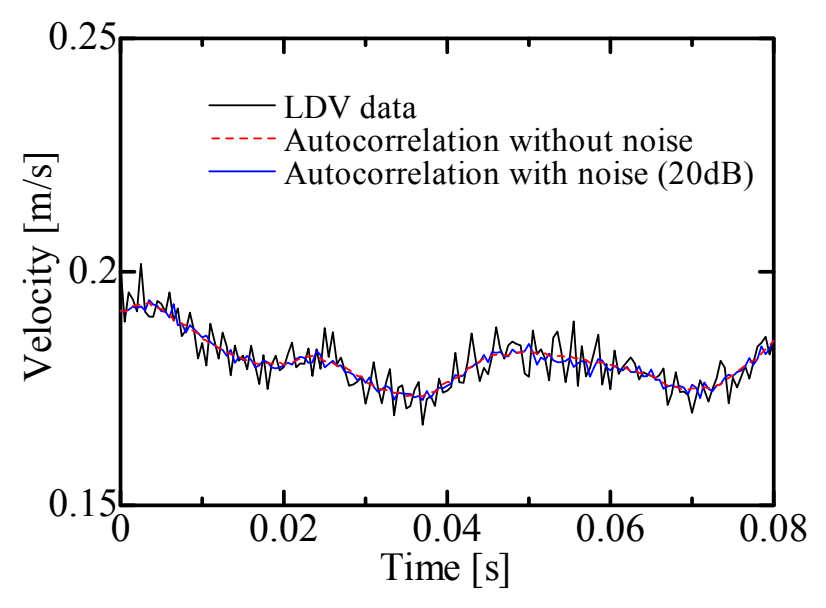

(b) $N_{\text {pulse }}=16$

Fig.4 Time-series of velocity compared between noise conditions (Autocorrelation)

図 5 にノイズが無い条件で解析した速度の標準偏差 $v^{\prime}$, 誤差の二乗平均 $\sigma$ と $N_{p u l s e}$ との関係を示す. 自己相関法 による $N_{\text {pulse }}=2$ では, 真值とほぼ一致した. $N_{\text {pulse }}$ が減少するにつれて FFT の周波数分解能が低下し, 最大值をと るスペクトルの分布が広がるため, スペクトルの最大值とその他の周波数によるスペクトル值の差が小さくなる. 極端に周波数分解能が悪い $N_{p u l s e}=4$ ではそれらが顕著となり, FFT-ave では $v^{\prime}, \sigma$ ともに特異な值を示している. 一方 FFT-max では, $N_{\text {pulse }}=4$ でもスペクトルの最大值をガウス補間することで，比較的精度高く計測できること

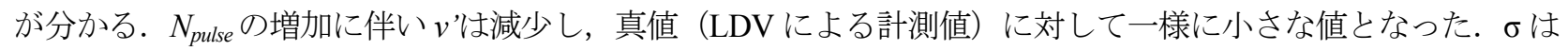
$N_{\text {pulse }}$ の増加に伴い増加した. これは時間分解能の低下に伴い, 早い速度変動が解析できなくなるためである. $N_{\text {pulse }}$ =4 64 ではFFT-ave と FFT-max による解析結果の違いがほとんど無く，良好に解析できることが分かる．それ に対して自己相関法では, FFTによる解析が不可能な $N_{\text {pulse }}=2$ では真值とほぼ一致するが, それ以外の $N_{\text {pulse }}$ では FFT による解析結果よりも悪い結果となった。位相の平均值を算出する自己相関法は， $N_{\text {pulse }}$ のデータで瞬時速度 を時間方向に移動平均寸るのと等価である. よって時間分解能 $\Delta t=N_{p u l s e} / f_{p r f}$ となる. FFT では, $N_{p u l s e}$ のデータに おける主たる周波数成分を算出するものであり, $\Delta t$ は $N_{p u l s e} / f_{p r f}$ 以下と見なせる. 図 6 に $N_{p u l s e}=128$ における FFT-max と自己相関法によって解析した時系列速度データを示寸．自己相関法では，LDVによるデータを $\Delta t=$ 0.064 秒毎に移動平均したものと同じになり，それ以下の周期の速度変動を再現することができない，一方 FFT-max では, 周期が 0.064 秒以下の大きな速度変動が解析できており, 同一の $N_{\text {pulse }}$ で解析を行った場合, 自己 相関法に比べFFT-max の時間分解能が高いことが分かる.

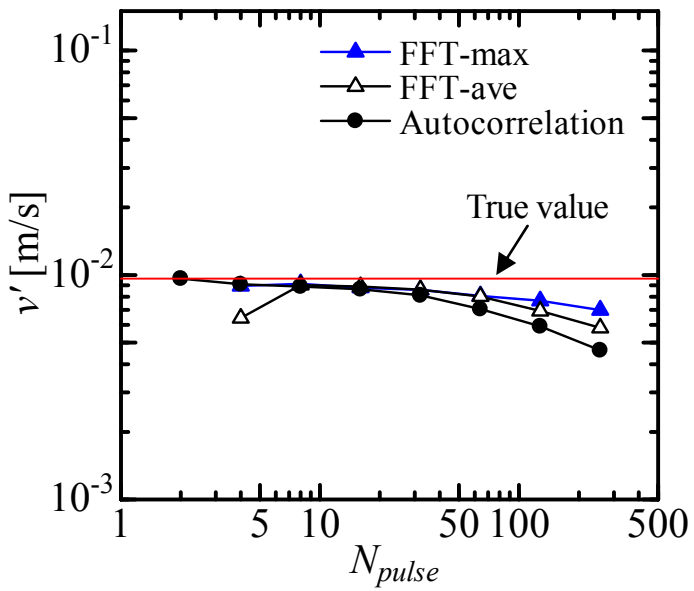

(a) Velocity standard deviation

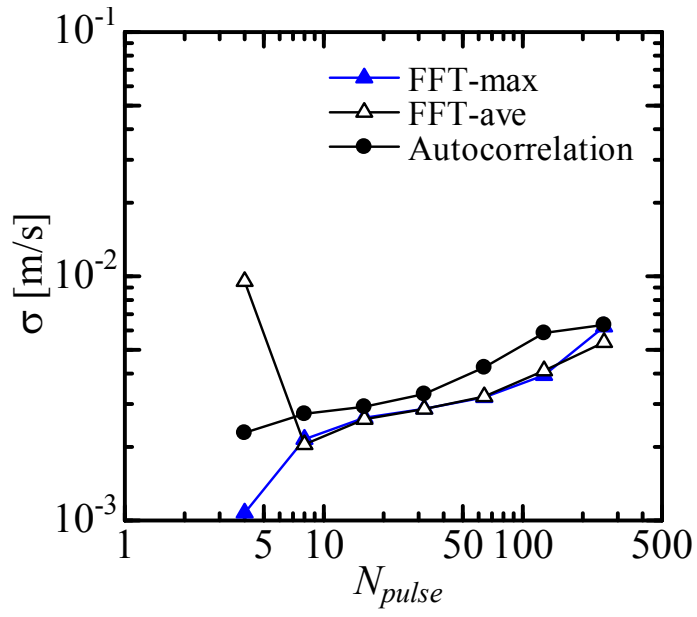

(b) Mean squared error

Fig.5 Simulation results under without-noise condition 


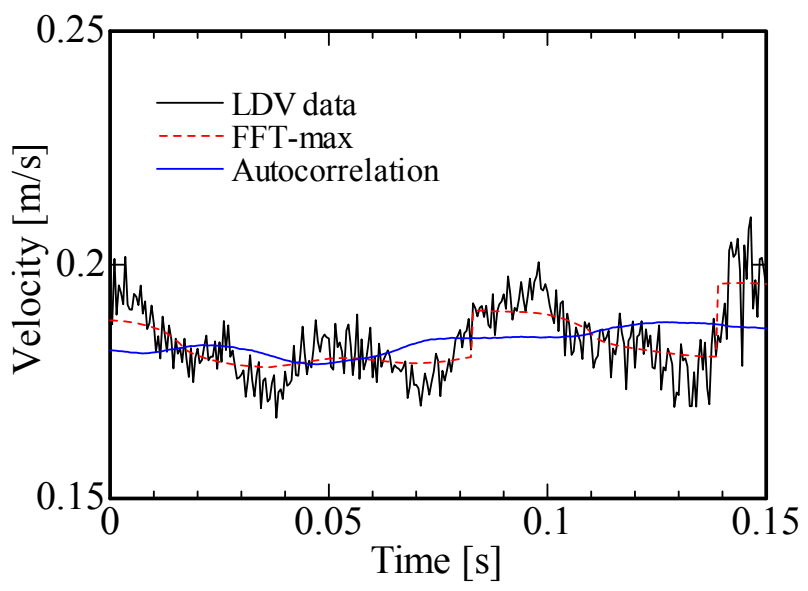

Fig.6 Time-series of velocity compared between FFT-max and Autocorrelation $\left(N_{\text {pulse }}=128\right)$

図 7 に SNR $=20 \mathrm{~dB}, 5 \mathrm{~dB}$ のホワイトノイズを付加して解析した時間平均速度 $\bar{v}, v$ および $\sigma$ を示す. 平均速度 について，SNR=20dB ではFFT-ave を除いて各条件で真值とほぼ一致するが，SNR=5dB において，FFT-max お よび自己相関法では $N_{\text {pulse }}=32$ 以上の時に真值とほぼ一致し, FFT-ave ではどの $N_{\text {pulse }}$ を用いても真值に対して解 析值が小さくなった. ホワイトノイズを付加したため, 各周波数スペクトルのノイズ成分は一定值 $\left(=P_{\text {noise }}\right)$ となる. 式(7)においてノイズを付加すると，

$$
f_{d, i}=\frac{\sum_{k=1}^{N_{\text {puss }} / 2+1} f_{k}\left(P_{a, i}\left(f_{k}\right)-P_{t, i}\left(f_{k}\right)\right)}{\sum_{k=1}^{N_{\text {puls }} / 2+1}\left(P_{a, i}\left(f_{k}\right)+P_{t, i}\left(f_{k}\right)+2 P_{\text {noise }}\right)}
$$

となる.よってノイズのある条件では $N_{\text {pulse }}$ に関わらす $f_{d}$ が真值より小さくなり, これはノイズの増加に伴い顕著 となる. $P_{\text {noise }}$ を信号の平均などによって評価する手法が一部検討されている ${ }^{(10)}$ が, 少ないパルス数で適切に $P_{\text {noise }}$ を評価するのは困難であり，ノイズの多い条件では FFT-ave は計測に適さないことが分かる.

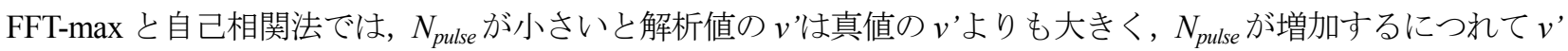
は一様に低下した. これは図 4 に示寸速度の時系列データからも分かるように, $N_{p u l s e}$ の増加に伴いノイズによる 速度誤差が減少し, さらに時間分解能が低下寸るためである. 誤差の二乗平均は $N_{\text {pulse }}$ の変化に伴い変化し, SNR $=20 \mathrm{~dB}$ では $N_{\text {pulse }}=16$ (FFT-max, 自己相関法), $\mathrm{SNR}=5 \mathrm{~dB}$ では $N_{\text {pulse }}=32$ (FFT-max）および $N_{\text {pulse }}=64$ （自己相 関法）で各アルゴリズムの最小值となり，更に $N_{\text {pulse }}$ を増加させると $\sigma$ が大きくなった．最小值となる $N_{\text {pulse }}$ での $v^{\prime}$ は真值よりも小さいことがわかる.これは $N_{\text {puse }}$ が小さいと, ノイズによる影響で速度の計測誤差が増加し, $v^{\prime}$,

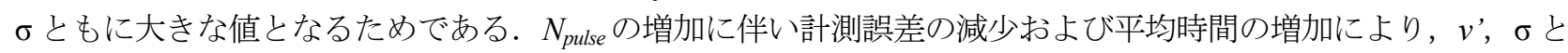
もに減少する. $\sigma$ が最小となる $N_{\text {pulse }}$ 以上では, ノイズによる計測誤差に比べ時間分解能の低下に伴う誤差が増加 し， $\sigma$ が増加する. よって各条件によって最適な $N_{\text {pulse }}$ が存在し， $\sigma$ を最少とする $N_{\text {pulse }}$ が最適值であることが分か る. $20 \mathrm{~dB}$ と $5 \mathrm{~dB}$ の結果を比較すると, FFT-max において $N_{\text {pulse }}=32$ ( $5 \mathrm{~dB}$ における最適值) 以上では $v$ ， $\sigma$ とも にほぼ同じ值になったが，自己相関法では $N_{p u l s e}=64 （ 5 \mathrm{~dB}$ における最適值）以上において，特に $\sigma$ 夺きく異な っている. よってノイズが少ない条件ではFFT-max および自己相関法による違いはあまり大きくないが，ノイズ が多い条件では, 自己相関法に比べSNR の違いによる計測結果への影響が小さい FFT-max が有利であると考え られる。 

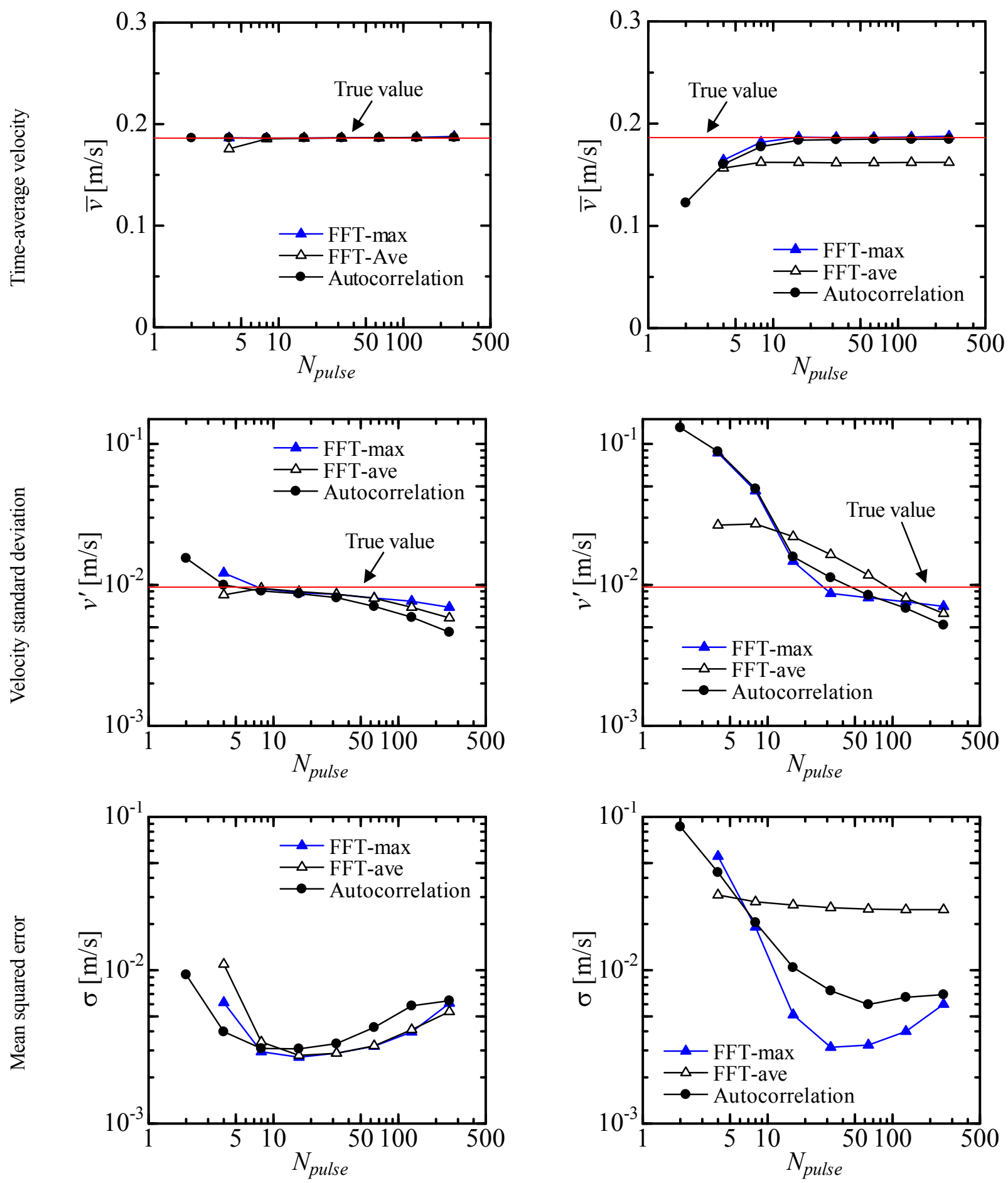

(a) $\mathrm{SNR}=20 \mathrm{~dB}$

(b) $\mathrm{SNR}=5 \mathrm{~dB}$

Fig.7 Simulation results under noise condition

\section{4. 実験による比較}

\section{$4 \cdot 1$ 実験方法}

パルサ・レシーバ(JPR-10C-KB, ジャパンプローブ)によって超音波の送受信を行い, 高速デジタイザ(PXI-5114, ナショナルインスツルメンツ）で波形データを連続的に取得した．同一の波形データを用いてアルゴリズムおよ び $N_{\text {pulse }}$ を変化させて速度算出を行い，実際の流れ場計測において，各アルゴリズムおよび $N_{p u l s e}$ にる影響を評 価した. 
図 8 に試験部の概略図を示寸. 試験部は幅 $(W) 50 \mathrm{~mm}$, 高さ $(H) 25 \mathrm{~mm}$, 水力等価直径 $(D) 33 \mathrm{~mm}$ の水平矩形管 で, 作動流体は温度 $19 \sim 21^{\circ} \mathrm{C}$ 水とし, $R e=8000$ で計測した. 超音波の反射体としてナイロン粒子（平均粒径 $80 \mu \mathrm{m}$, 比重 1.02）を $0.1 \mathrm{~g} / \mathrm{l}$ の割合で懸濁させた. センサ径 $3 \mathrm{~mm}$, 基本周波数 $8 \mathrm{MHz}$ の超音波トランスデューサ を流路上部に流れ方向に対して $45^{\circ}$ の角度で, 音響インピーダンス整合のため水ボックスを用いて流路入口から $75 D$ の位置に設置した. $f_{p r f}=8 \mathrm{kHz}, 1$ パルスの波数は 8 とした. これらの設定によって測定体積は直径約 $3 \mathrm{~mm}$, 厚さ $0.74 \mathrm{~mm}$ の円盤状となる. 計測範囲での超音波ビームの幅はほぼ一定であり, 計測位置による測定体積の違 いが小さいことを確認している．壁面近傍は測定体積による影響で実際の計測位置にズレが生じる．そのため， 測定体積における重心を基準とした計測位置の補正 ${ }^{(13)}$ を行った．比較計測には測定体積 $\varphi 0.13 \times 1.5 \mathrm{~mm} の \mathrm{LDV}$

（Smart LDV II，日本カノマックス）を用いた. LDVによる計測にも誤差が含まれるが, 測定体積が超音波に比 べて小さいこと, 時間分解能が高いことから, 乱流計測では超音波よりも早い速度変動を再現可能であると考え られる. UVP では測定線方向の速度成分が計測される．そこで流れに対して $45^{\circ}$ 方向の速度成分を計測するよう に LDV を設置し, 超音波と測定速度成分を一致させた. 壁面近傍では物理的な制約により LDVによる計測はで きなかった. 平均速度は主流方向の速度成分に変換し, 速度の標準偏差は主流に対して $45^{\circ}$ 方向成分速度 $v^{\prime}{ }_{+45^{\circ}}$ と して示寸.

ノイズによる影響を評価するため, パルサ・レシーバの受信ゲインを $30 \mathrm{~dB}$ および $20 \mathrm{~dB}$ の 2 種類に設定して計 測した．今回の実験では $30 \mathrm{~dB}$ の設定が最適に計測できる条件であり, 計測領域において $\mathrm{SNR}=20 \sim 10 \mathrm{~dB}$ 程度で あった．これをノイズの少ない条件と記す．受信ゲインが $20 \mathrm{~dB}$ の設定では信号強度の増幅が少ないためノイズ が多くなり，計測領域において $\mathrm{SNR}=10 \sim 0 \mathrm{~dB}$ となった。この条件をノイズの多い条件とする.

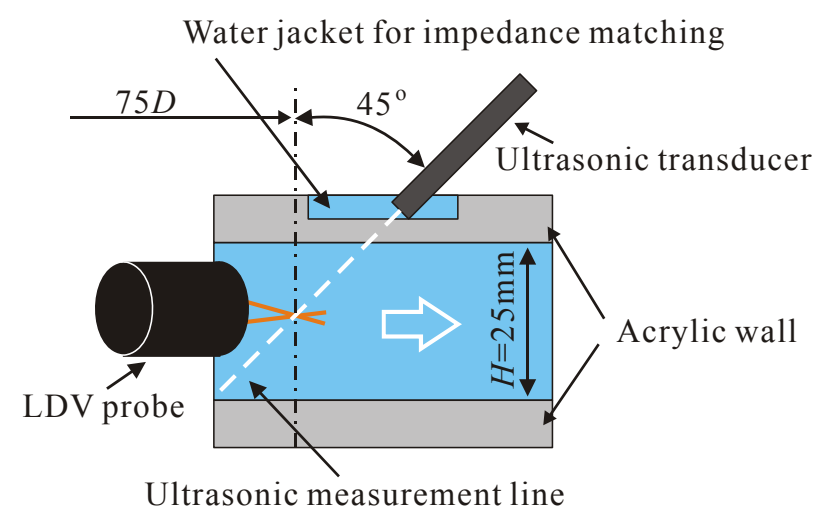

Fig.8 Schematic of test section

\section{$4 \cdot 2$ 実験結果}

図 9 にノイズの少ない条件において, FFT-max および自己相関法を用いて解析した速度分布および標準偏差を 示す. $N_{\text {pulse }}=8 \sim 128$ の比較で, 一つの瞬時速度の計測に要する時間はそれぞれ 1 16 ms である. 横軸は上部壁面 からの距離 $y$ を $H$ で正規化した值である. 自己相関法による $N_{\text {puse }}=8$ では平均速度分布は良好に一致しているが, 標準偏差は大きくバラつき, 計測誤差が多く含まれることが分かる. 二つの解析手法ともに $N_{p u l s e}=16$ の標準偏 差では，センサから近い壁面側の領域では LDV の結果に比べて小さな值となり，遠くなるにつれて大きな值と なった. 超音波計測による SNR は一般的にセンサからの距離に依存し, 離れるにつれて超音波の減衰に伴い SNR が低下寸る. $N_{\text {pulse }}=16$ では壁面に近い領域では十分な繰り返し数であったが, 壁面から離れるに伴い SNR が低 下寸ることでノイズに起因する計測誤差が増加し, LDVによる結果と比べて標準偏差が高い值になったと考えら れる. そのため本条件では, FFT-max, 自己相関法ともに全ての計測位置で標準偏差が LDV より小さな值となる $N_{\text {pulse }}=32$ が, 最適な条件であると推定できる. FFT-max と自己相関法との比較では, 同じ $N_{\text {puse }}$ において FFT-max の方が高い值となった. 特に壁面近傍の領域では顕著であり, FFT-max の方が自己相関法に比べて速度变動を再 現しやすいことが分かる. 

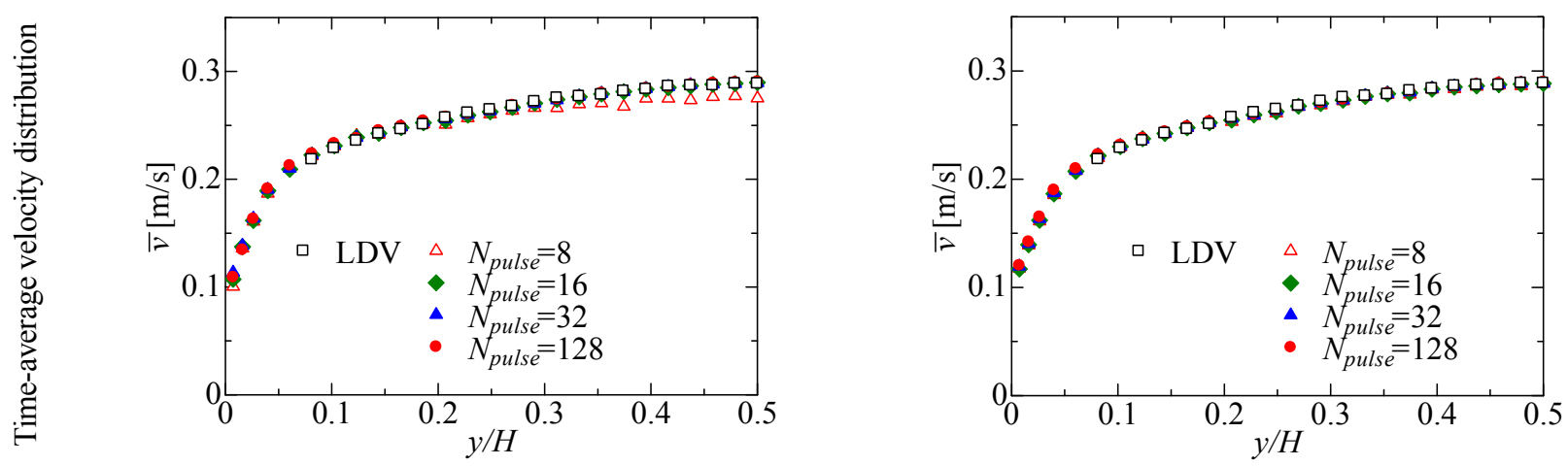

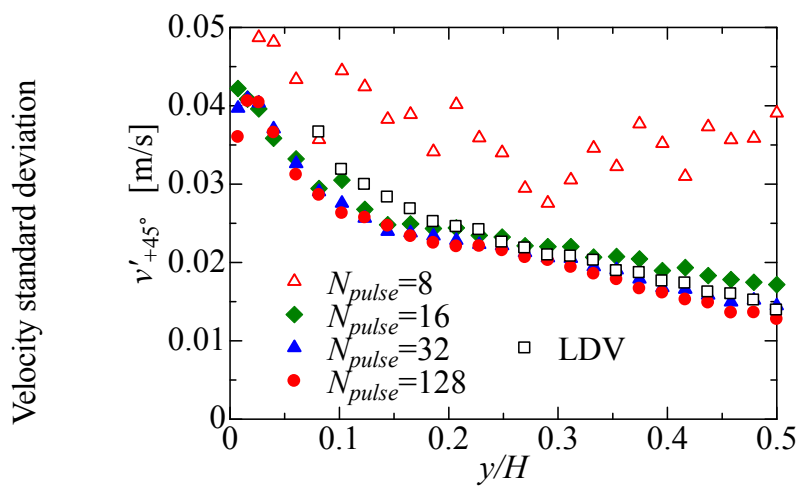

(a) FFT-max

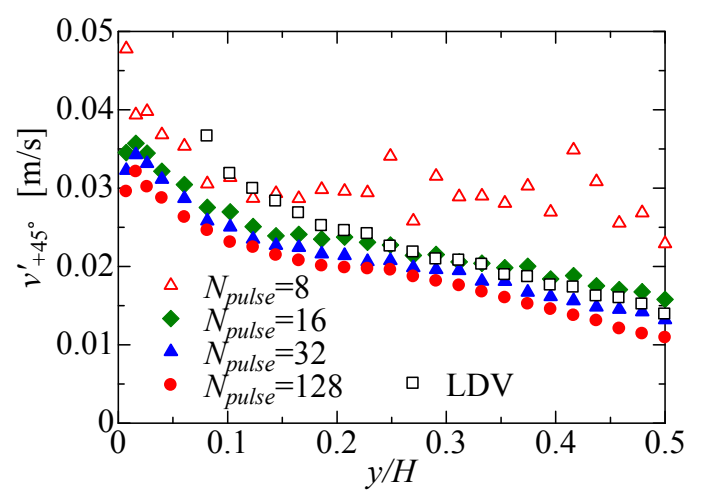

(b) Autocorrelation

Fig.9 Experimental results under lower-noise condition

図 10 にノイズの多い条件における結果を示寸.ノイズが多くなることで最適な $N_{\text {pulse }}$ が増加し, 本条件では $N_{\text {pulse }}$ $=128$ が最適值であると推定できる. $N_{\text {pulse }}=128$ による標準偏差をノイズの少ない条件と多い条件で比較すると, FFT-max ではほぼ同じ分布となっているが，自己相関法ではノイズの多い条件の方が，特に流路中央付近におい てわずかに標準偏差が高くなっている。これはFFT-max において $N_{\text {puse }}$ を最適值以上に設定した場合, SNR の違 いによる v’への影響が小さいことを示しており，解析結果とも良く一致する. FFT-max ではスペクトルの最大值 から $f_{d}$ を求めるため, ノイズによって生じるスペクトル成分の影響を受けにくい. 自己相関法では，ノイズによ って生じる位相誤差を平均するため, ノイズの影響を受け易いためである. 実際の超音波計測では SNR が計測位 置によって変化する. そのため, SNRの違いによるv’への影響が最も小さい FFT-max を用い, SNR が最も低い 計測位置 (一般的には最も遠い計測位置) において $N_{p u l s e}$ の最適值を決めることで，ノイズによる計測誤差を最も 小さくできると言える. 

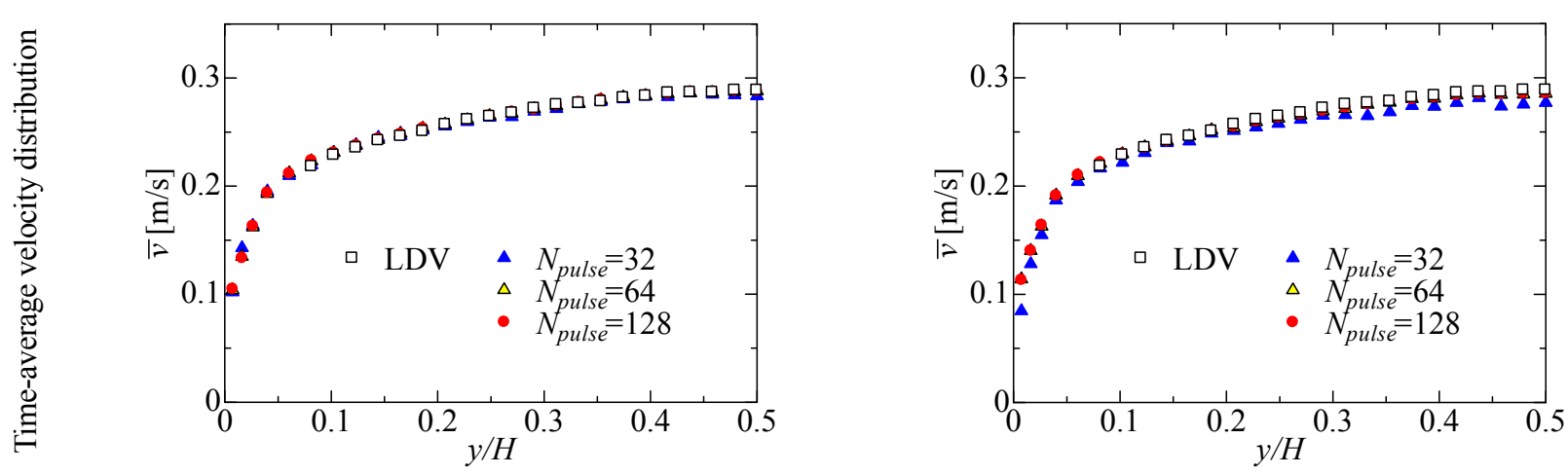

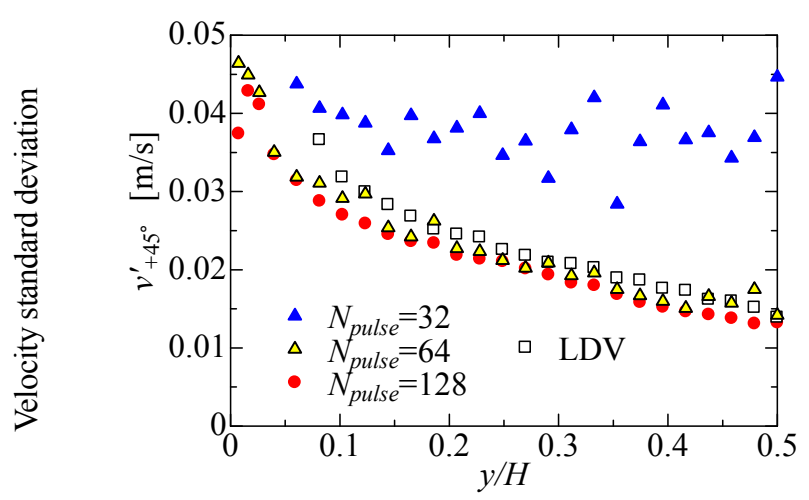

(a) FFT-max

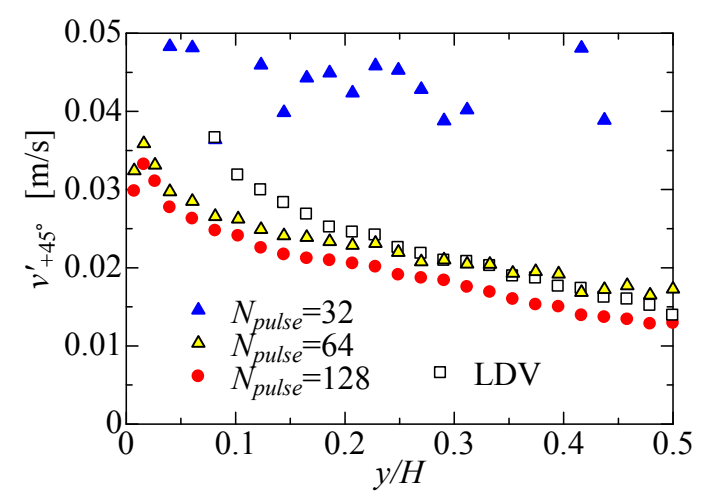

(b) Autocorrelation

Fig.10 Experimental results under higher-noise condition

\section{5. 結語}

超音波パルスドップラ法において, 速度算出に用いる周波数解析アルゴリズム, $N_{\text {pulse }}$ およびノイズの違いによ る速度解析結果への影響を評価するため，周波数解析手法に FFT-ave，FFT-max および自己相関法を用いて擬似 ドップラ信号によるシミュレーションおよび実際の流れ場計測を行った.

1.ノイズの少ない条件では，各アルゴリズムによる解析結果の違いは小さいが，ノイズが多い条件では FFT-ave による解析は適さず，FFT-max が短時間の速度変動を再現し易い.

2. ノイズの影響により FFT-max, 自己相関法の解析では最適な $N_{\text {pulse }}$ が存在し，その值は SNR の低下に伴 い増加する.

3. FFT-max において最適な $N_{\text {pulse }}$ 以上の值による解析では, SNR の違いによる標準偏差の違いはあまり無か った.

実際の流体計測では SNR が計測位置によって変化し，最適な $N_{\text {pulse }}$ が計測位置によって変化するため，SNR が 最も低い計測位置で最適な $N_{\text {pulse }}$ を設定する必要がある．解析手法には，SNR による計測結果への影響が小さい FFT-max が適している. $N_{\text {pulse }}$ の増加によってノイズによる誤差が減少するが, 必要以上に大きな $N_{\text {pulse }}$ を設定す ると, 速度変動を過少に評価することに加え, 計測時間が長くなるということに注意が必要である.

\section{謝 辞}

本研究の一部は JSPS 科研費 24760135 の助成を受けて実施された.

\section{文献}


(1) Baker, D.W., "Pulsed ultrasonic Doppler blood-flow sensing", IEEE Transactions on Sonics and Ultrasonics, Vol. SU-17, No. 3 (1970), pp.170-185.

(2) Takeda,Y., "Development of an ultrasound velocity profile monitor", Nuclear Engineering and Design, Vol. 126 (1991), pp. 277-284.

(3) Wada, S., Kikura, H., Aritomi, M., Mori, M. and Takeda, Y., "Development of Pulse Ultrasonic Doppler Method for Flow Rate Measurement in Power Plant Multilines Flow Rate Measurement on Metal Pipe”, Journal of Nuclear Science and Technology, Vol. 41, No. 3 (2004), pp. 339-346.

(4) Kikura, H., Takeda, Y. and Durst, F., "Velocity Profile Measurement of the Taylor Vortex Flow of a Magnetic Fluid using the Ultrasonic Doppler Method”, Experiments in Fluids, Vol. 26 (1999), pp. 208-214.

(5) Murakawa, H., Kikura, H. and Aritomi, M., “Application of Ultrasonic Doppler Method for Bubbly Flow Measurement using Two Ultrasonic Frequencies”, Experimental Thermal and Fluid Science, Vol. 29, No. 7 (2005), pp. 843-850.

(6) Takeda, Y. (ed.), Ultrasonic Doppler Velocity Profiler for Fluid Flow (2012), Springe.

(7) 千原國宏, 超音波 (2001), コロナ社.

(8) Jensen, J.A., Estimation of blood velocities using ultrasound (1996), Cambridge University Press.

(9) Embree, P.M. and O’Brien, W.D., Jr., "Pulsed Doppler accuracy assessment due to frequency-dependent attenuation and Rayleigh scattering error sources”, IEEE Transactions on Biomedical Engineering, Vol. 37, No. 3 (1990), pp.322-326.

(10) Barber, W.D., Eberhard, J.W. and Karr, S.G., "A new time domain technique for velocity measurements using Doppler ultrasound", IEEE Trans. on Biomedical Engineering, Vol. BME-32, No. 3 (1985), pp.213-229.

(11) Kasai, C., Namekawa, K., Koyano, A. and Omoto, R., "Real-Time Two-Dimensional Blood Flow Imaging Using an Autocorrelation Technique", IEEE Transactions on Sonics and Ultrasonics, Vol. SU-32, No. 3 (1985), pp. 458-464.

(12) Matani, A., Oshiro, O. and Chihara, K., "Doppler Signal Processing of Blood Flow using a Wavelet Transform", Japanese Journal of Applied Physics, Vol. 35, Part 1, No. 5B (1996), pp.3131-3134.

(13) Taishi, T., Kikura, H. and Aritomi, M., "Effect of the measurement volume in turbulent pipe flow measurement by the ultrasonic velocity profile method", Experiments in Fluids, Vol.32 (2002), pp.188-196. 